\title{
Mutagênese sítio-dirigida da xilanase (XynA) de Orpinomyces sp. PC-2 para aumento da termoestabilidade
}

\author{
Maria Isabella Petra Souza*, Rafaela Zandonade Ventorim, Larissa \\ Mattos Trevizano, Valéria Monteze Guimarães. \\ Departamento de Bioquímica e Biologia Molecular, Universidade Federal de Viçosa, 36571-000. Viçosa/MG, Brasil \\ *e-mail: isabella.petra@gmail.com
}

\section{Resumo}

O presente trabalho consiste na manipulação genética de xilanases derivadas do gene xynA de Orpinomyces com a finalidade de aprimorar suas características para uso na indústria de papel e celulose. A metodologia de mutagênese sítiodirigida foi empregada a fim de obter xilanases mutantes com maior estabilidade, mais adequadas aos processos industriais. A partir de enzimas mutantes previamente obtidas por error-prone PCR, estudos de modelagem e dinâmica molecular permitiram identificar regiões flexíveis da estrutura e resíduos para serem deletados de forma a aumentar a rigidez e permitir a obtenção de enzimas mais termoestáveis. Os resíduos identificados foram G10, T30, N53, Q109 e G110. A enzima sem deleções, SWT foi utilizada como controle e molde para as deleções. Os mutantes de SWT com as respectivas deleções, SWT T30, SWT N53 e SWT Q109/G110, foram obtidos. Oss genes que codificam para as xilanases mutantes foram expressos em E. coli/pET24b. Após superexpressão das enzimas, o extrato enzimático intracelular foi testado quanto à concentração de proteína e atividade enzimática, utilizando como substrato xilana Oalt Spelts 1\% ressuspendida em tampão fosfato de sódio 100 $\mathrm{mM}, \mathrm{pH}$ 6,5. Enquanto a xilanase SWT apresentou atividade específica de 5446,5 U.mg ${ }^{-1}$, SWT T30, SWT N53 e SWT Q109/G110 apresentaram atividade específica de 4165,4; 759,8 e 3364,2 U.mg-1, respectivamente. Após a caracterização das enzimas mutantes obtidas, espera-se a identificação de enzimas mais termoestáveis que posteriormente serão testadas sob as condições de branqueamento da polpa de celulose na indústria de papel. 
Palavras-chave: xilanase, mutagênese sítio-dirigida, termoestabilidade.

Apoio financeiro: CNPq e FAPEMIG

Souza, Maria Isabella Petra; Ventorim, Rafaela Zandonade; Trevizano, Larissa Mattos; Guimarães, Valéria Monteze; "MUTAGÊNESE SÍTIO-DIRIGIDA DA XILANASE (XYNA) DE ORPINOMYCES SP. PC-2 PARA AUMENTO DA TERMOESTABILIDADE", p. 27-28 . In: Anais da V Jornada Acadêmica Internacional de Bioquímica [= Blucher Biochemistry Proceedings, v.1, n.1]. São Paulo: Blucher, 2015. DOI 10.5151/biochem-jaibqi-0037 